\title{
Evaluasi Kuat Tumpu Alat Sambung Baut pada Papan WPC dari Limbah Sengon dan Plastik HDPE
}

\author{
Yudhi Arnandha \\ Program Doktor Program Pascasarjana Fakultas Teknik, Universitas Gadjah Mada, \\ Jl. Grafika No. 2 Kampus UGM Yogyakarta \\ E-mail: yudhiarnandha@untidar.ac.id \\ Iman Satyarno \\ Departemen Teknik Sipil dan Lingkungan, Universitas Gadjah Mada, \\ Jl. Grafika No. 2 Kampus UGM Yogyakarta \\ E-mail: iman@tsipil.ugm.ac.id \\ Ali Awaludin \\ Departemen Teknik Sipil dan Lingkungan, Universitas Gadjah Mada, \\ Jl. Grafika No. 2 Kampus UGM Yogyakarta \\ E-mail: ali.awaludin@ugm.ac.id \\ Arfiati Fardhani \\ Departemen Teknik Sipil dan Lingkungan, Fakultas Teknik, Universitas Gadjah Mada, \\ Jl. Grafika No. 2 Kampus UGM Yogyakarta \\ E-mail: arfiatifardhani@gmail.com
}

\begin{abstract}
Wood Plastic Composite (WPC) is wood based material that been produce by mixing sawdust as main composition and plastic polymer as bonding agent. Nowadays, WPC board already been produced in Indonesia using Sengon sawdust and recycle HDPE plastic. Sengon sawdust was used as WPC since its availability from plywood production waste, moreover HDPE plastic considered had higher strength and more rigid than PET plastic. WPC occasionally being used as non structural material, moreover from previous study about mechanical properties of WPC, it was found that WPC Sengon has high shear strength around 25 - $30 \mathrm{MPa}$. These lead that WPC Sengon had a potential used as shear wall sheathing, thus additional research need to be conducted in order to study the type of bolt and diameter of the bolt can be used for these shear wall. This study aimed to investigate the dowel bearing of bolt using full hole method based on ASTM D5764 with type and bolt diameter as specimen variation. Two types of bolt were used in this study; stainless bolt and standard bolt with diameter each of $6 \mathrm{~mm}, 8 \mathrm{~mm}, 10 \mathrm{~mm}$ and $12 \mathrm{~mm}$. According to ANOVA, there was insignificant result between stainless bolt and standard one, but there was significant result based on diameter of the bolt. Hereafter, it can be recommended the used of $10 \mathrm{~mm}$ diameter of bolt for structural purpose with dowel bearing strength around $67-70 \mathrm{MPa}$.
\end{abstract}

Keywords: WPC, Sengon, Dowel-bearing, Bolt.

\begin{abstract}
Abstrak
Wood Plastic Composite (WPC) adalah material turunan kayu yang diperoleh dengan mencampurkan bubuk kayu sebagai penyusun dasar dan polimer plastik sebagai material pengikatnya. Salah satu jenis WPC yang diproduksi di Indonesia adalah dalam bentuk papan berasal dari bubuk kayu Sengon dan sampah plastik jenis HDPE. Kayu Sengon digunakan karena limbah dari hasil pemotongan untuk kayu lapis mudah diperoleh, sedangkan plastik jenis HDPE daur ulang dipilih karena lebih kuat dibanding plastik jenis PET. WPC pada umumnya digunakan sebagai material non struktural, namun berdasarkan pengujian sebelumnya
\end{abstract}


terhadap sifat mekanik papan WPC Sengon diperoleh nilai kuat geser berkisar 25 - 30 MPa. Berdasar hasil tersebut maka papan WPC Sengon memiliki potensi untuk digunakan sebagai penutup (sheathing) dinding geser, oleh karenanya perlu dilakukan penelitian lanjutan untuk mengetahui jenis dan diameter alat sambung baut yang dapat digunakan pada penutup dinding geser tersebut. Penelitian ini bertujuan untuk mengetahui kemampuan kuat tumpu (dowel bearing) alat sambung baut dengan skema pengujian full hole test berdasar pada papan WPC Sengon berdasar standar ASTM D5764-97a dengan variasi berupa jenis baut serta diameter baut. Baut yang digunakan adalah baut tahan karat (outdoor) dan baut standar (indoor) dengan diameter $6 \mathrm{~mm}, 8 \mathrm{~mm}, 10 \mathrm{~mm}$ dan $12 \mathrm{~mm}$. Berdasarkan analisis statistik ANOVA, tidak terdapat perbedaan signifikan pada jenis baut antara baut tahan karat dan standar namun terdapat perbedaan signifikan untuk kuat tumpu baut berdasarkan diameternya sehingga dapat direkomendasikan penggunaan baut diameter 10 mm dengan kuat tumpu tertinggi berkisar antara $67-70 \mathrm{~N} / \mathrm{mm}^{2}$.

Kata-kata Kunci: WPC, Sengon, Dowel-bearing, Baut.

\section{Pendahuluan}

Kayu telah digunakan sebagai bahan konstruksi oleh masyarakat Indonesia sejak jaman dahulu karena memiliki sifat awet, mudah dibentuk, ringan, mudah diperoleh dan dapat terurai oleh alam (biodegradable). Kayu dipakai untuk tujuan struktural maupun non struktural, tergantung jenis kayu yang digunakan. Indonesia sendiri dikenal sebagai negara eksportir kayu, menurut Data Statistik Kementerian Kehutanan (2014) kayu hasil hutan Indonesia paling banyak digunakan sebagai kayu lapis yaitu mencapai 3,262 juta $\mathrm{m}^{3}$ dalam jangka waktu setahun. Kayu yang umumnya digunakan untuk membuat produk kayu lapis adalah jenis Sengon (paraserianthes falcataria) karena usia panen kayu yang relatif pendek yaitu $5-7$ tahun

Proses pembuatan kayu lapis menghasilkan limbah sisa produksi dalam bentuk potongan kecil, serbuk kasar (chip), dan debu (sawdust). Berdasarkan resiko tingkat berbahaya, maka debu adalah limbah produksi yang paling berbahaya karena apabila terhirup maka dapat menimbulkan gangguan sistem pernapasan. Untuk mengatasi hal tersebut, banyak pabrik industri kayu kemudian membakarnya sebagai bahan bakar tungku pemanas atau penggerak mesin, namun asap yang dihasilkan juga berbahaya bagi lingkungan sekitarnya.

Selama beberapa dekade ini, telah dikembangkan produk komposit turunan kayu dengan komposisi utama terdiri dari debu kayu dan polimer termoplastik sebagai pengikatnya melalui suatu mekanisme cetak ekstrusi menggunakan suhu tinggi yang dikenal dengan istilah Wood Plastic Composite (WPC). Menurut Tarbasa, et al., 2011 definisi dari WPC itu sendiri adalah material komposit yang terdiri dari kayu (berbagai bentuk) dan material yang bersifat termoplastik.

WPC memiliki permukaan yang lebih halus, murah, awet, dapat diperbaharui dan merupakan material yang pada akhirnya dapat terurai. WPC dapat dianggap sebagai produk ramah lingkungan karena memberikan solusi alternatif pemanfaatan limbah debu kayu pada industri pengolahan kayu. Polimer plastik yang digunakan pada WPC dapat berupa polimer murni (virgin) ataupun hasil olahan daur ulang (recycled). Penggunaan plastik daur ulang berpotensi mengurangi jumlah sampah plastik yang sangat sulit terurai di alam.

Material WPC belum banyak dipakai di Indonesia karena hingga saat ini belum banyak pabrik yang memproduksi produk turunan kayu ini, hal ini secara langsung menyebabkan harga jual WPC menjadi relatif mahal. Produk WPC sendiri telah lama dikembangkan di Eropa sebagai material pengganti kayu karena memiliki beberapa keunggulan, diantaranya yaitu lebih awet karena cenderung kedap air, lebih mudah dibentuk karena dapat dicetak berdasarkan ukuran dan bentuk tertentu, lebih murah karena tidak memerlukan perawatan anti rayap dan jamur seperti halnya kayu biasa. Selama ini WPC digunakan hanya untuk tujuan non struktural karena sebagai produk yang dibuat dari limbah (secondary product) lantas dianggap memiliki sifat mekanis yang rendah. Berdasarkan pengujian pendahuluan diperoleh hasil bahwa kuat geser WPC Sengon mencapai 25 - $30 \mathrm{MPa}$, lebih tinggi dibandingkan papan kayu lapis maupun papan kayu Sengon pada umumnya. Namun WPC memiliki modulus elastisitas rendah karena sifat getas yang dimilikinya, oleh karenanya salah satu potensi WPC Sengon sebagai material structural adalah digunakan untuk dinding geser (Arnandha, 2008). Kayu dan produk turunan kayu memiliki ketahanan terhadap gempa lebih baik dikarenakan perbandingan antara kekuatan dan densitasnya. Alat sambung dari bahan logam direkomendasikan pada sambungan kayu karena memiliki energi disipasi lebih besar dan gaya inersia yang terbatas (Humbert dkk, 2014).

Sambungan diperlukan mengingat material memiliki keterbatasan ukuran dan panjang, 
keterbatasan luasan material dan keterbatasan kekuatan material. Dibutuhkan studi lebih lanjut perihal alat sambung yang dapat digunakan pada WPC Sengon untuk tujuan struktural, yaitu jenis baut yang digunakan dan diameter baut yang harus dipakai. Pada penelitian ini digunakan 2 jenis baut yang beredar di pasaran yaitu baut tahan karat dan baut standar. Untuk masing-masing jenis baut digunakan diameter yang berbeda yaitu $6 \mathrm{~mm}, 8$ $\mathrm{mm}, 10 \mathrm{~mm}$ dan $12 \mathrm{~mm}$. Material WPC yang digunakan pada penelitian ini adalah produk lokal di daerah Tempuran, Kabupaten Magelang, menggunakan limbah kayu lapis Sengon yang dicampur dengan polimer plastik daur ulang jenis HDPE (High density polyethylene).

\section{Kuat tumpu (dowel bearing) baut}

Menurut Awaludin (2005) karena alasan geometrik, pada konstruksi sering diperlukan adanya sambungan yang dapat berfungsi untuk memperpanjang batang atau menggabungkan beberapa batang pada satu buhul. Secara umum, sambungan merupakan bagian terlemah dari suatu struktur. Kegagalan sering diakibatkan oleh gagalnya fungsi sambungan daripada kegagalan material bahan itu sendiri.

Untuk dapat mengetahui kapasitas kekuatan penyambung dan mekanisme kerusakan yang mungkin terjadi digunakan pendekatan European Yield Model (EYM). Beban lateral ultimit dari sambungan kayu dan alat sambung dapat diperoleh menggunakan teori "pelelehan" yang mengasumsikan mekanisme plastisitas pada kayu maupun alat sambung pengencangnya; metode ini kemudian dikenal dengan teori leleh (Aune dkk, 1986). Model teori ini menyederhanakan perilaku komplek pada sambungan, namun cukup akurat untuk menentukan kapasitas dukung secara nyata. Selain karakteristik geometri dari sambungan, terdapat parameter batas mekanis yaitu kekuatan dukung pada kayu di bawah baut dan tegangan leleh dari baut tersebut (Gattesco, 1998).

Pendekatan EYM berdasar pada beberapa asumsi dasar, asumsi pertama adalah material bersifat homogen dan berperilaku secara elastoplastis. Elemen kayu pada sambungan dimodelkan bersifat ortotropik, sedangkan alat sambung dimodelkan bersifat isotropik. Tegangan tarik dan geser yang muncul pada pasak diabaikan. Bagian ujung alat sambung diasumsikan dapat berotasi secara bebas. Asumsi yang lain adalah tegangan dukung kayu terdistribusi secara merata di bawah pasak. Asumsi yang terakhir adalah efek gesekan pada sambungan dianggap tidak ada. (McLain, 1983).
Penggunaan metode European Yield Model (EYM) telah banyak diaplikasikan untuk memperkirakan kuat leleh yang terjadi pada daerah sambungan. Menurut American Wood Council (2015), titik leleh nominal diperoleh di antara limit proporsional dan beban maksimum yang bekerja pada material dan sambungan. Grafik hubungan beban dan deformasi dapat dilihat pada Gambar 1 .

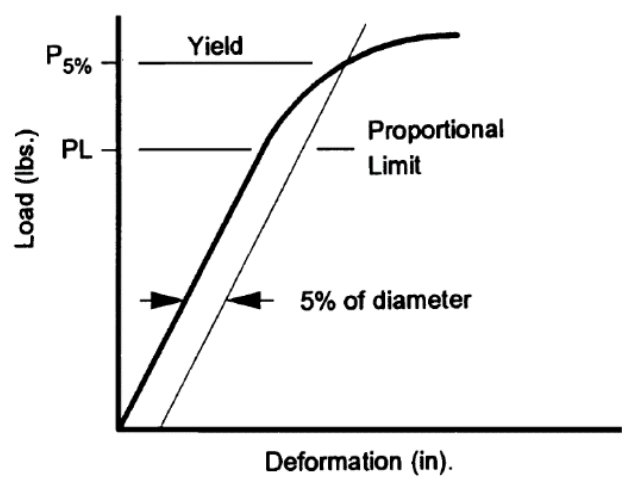

\section{Gambar 1. Penentuan titik leleh berdasar teori EYM}

Kuat tumpu (dowel bearing strength) adalah salah satu sifat mekanik yang digunakan untuk memperkirakan kekuatan alat sambung terhadap material yang ditinjau. (Hassan dkk, 2014). Menurut Awaludin (2007), pengujian full hole testing telah dikembangkan oleh Whale, dkk (1986) yang kemudian menjadi runutan pada Eurocode 5. Kuat tumpu dengan metode full hole testing dapat juga menggunakan standar ASTM D5764 - 97a (Standard Test Method for Evaluating Dowel-Bearing Strength of Wood and Wood-Based Products) dengan keterangan sebagai berikut:

a. Perilaku antara alat sambung dan daerah di sekitar alat sambung adalah perilaku deformasi akibat beban pada kayu atau produk turunan kayu dimana alat sambung tidak melentur saat pembebanan.

b. Kuat tumpu alat sambung dengan daerah di sekitar alat sambung adalah beban leleh yang diperoleh dari kurva hubungan deformasi dan beban dibagi dengan diameter alat sambung dan tebal benda uji.

c. Ukuran benda uji berbentuk kotak persegi panjang. Khusus untuk produk turunan kayu disesuaikan dengan ukuran tebal produk dari pabrikan. Tebal benda uji disesuaikan dengan ukuran produk, lebar harus lebih besar dari 2 inchi $(50 \mathrm{~mm})$ atau 4 kali diameter alat sambung, tinggi benda uji harus lebih besar dari 2 inchi $(50 \mathrm{~mm})$ atau 4 kali diameter alat sambung.

d. Kecepatan pembebanan sebesar 0,04 inchi/ menit. 
e. Skema pengujian dowel bearing test untuk metode full hole testing dapat dilihat pada Gambar 2.
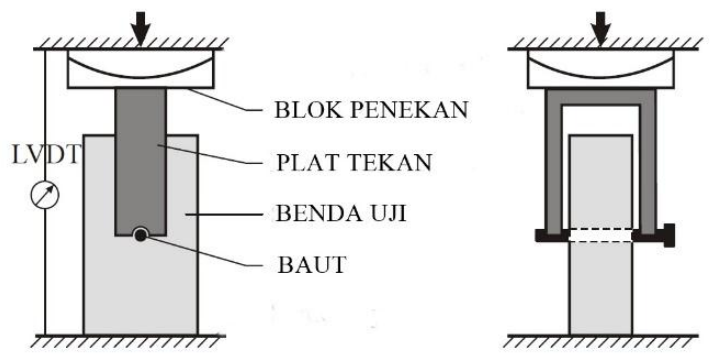

\section{Gambar 2. Skema pengujian dowel bearing strength full hole testing}

Hasil yang diperoleh dibedakan menjadi beban maksimum $\left(\mathrm{F}_{\text {ultimate }}\right)$ dan beban beban leleh $\left(\mathrm{F}_{\text {yield }}\right)$ yang ditentukan dengan metode EYM. Metode ini adalah suatu metode yang memprediksi kuat leleh dari alat sambung dengan parameter kuat tumpu pada bahan yang disambung, kuat lentur alat sambung dan ukuran spesifik dari sambungan tersebut. Kuat tumpu $\left(\mathrm{F}_{\mathrm{h}, \mathrm{y}}\right)$ untuk kondisi $5 \%$ offset diperoleh dengan menggunakan persamaan berikut:

$\mathrm{F}_{\mathrm{h}, \mathrm{y}}=\frac{\mathrm{F}_{\text {yield }}}{\mathrm{d} \cdot \mathrm{t}}$

dimana:

$\mathrm{d}=$ diameter baut

$\mathrm{t}=$ adalah tebal dari spesimen.

Sedangkan kuat tumpu $\left(\mathrm{F}_{\mathrm{h}, \mathrm{u}}\right)$ untuk kondisi ultimit diperoleh dengan menggunakan persamaan berikut:

$\mathrm{F}_{\mathrm{h}, \mathrm{u}}=\frac{\mathrm{F}_{\max }}{\mathrm{d} \cdot \mathrm{t}}$

dimana:

$\mathrm{d}=$ diameter baut

$\mathrm{t}=$ tebal dari specimen

\section{Pelaksanaan Pengujian}

Pengujian telah dilakukan di Laboratorium Mekanika Bahan, Pusat Studi Ilmu Teknik (PSIT) UGM, dengan menggunakan alat Universal Testing Machine (UTM) berdasarkan standar ASTM D5764 - 97a (Standard Test Method for Evaluating Dowel-Bearing Strength of Wood and Wood-Based Products). Papan WPC yang digunakan adalah Papan WPC Sengon dengan kode dagang 12600A produksi PT. Mega Prima Plastik, Tempuran, Magelang. Baut yang digunakan adalah baut tahan karat dan baut standar dengan variasi diameter $6 \mathrm{~mm}, 8 \mathrm{~mm}, 10 \mathrm{~mm}$, dan $12 \mathrm{~mm}$, seperti dapat dilihat pada Gambar 3 . Keterangan jumlah benda uji dapat dilihat pada
Tabel 1. Dimensi benda uji yang digunakan dapat dilihat pada Gambar 4. (a), sedangkan mekanisme pengujian dapat dilihat pada Gambar 4. (b).

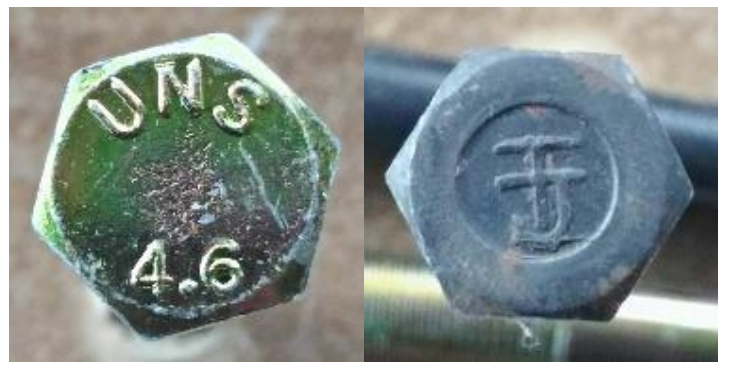

(a)

(b)

Gambar 3. (a) Baut tahan karat; (b) Baut standar

Tabel 1. Keterangan dan kode benda uji

\begin{tabular}{|c|c|c|c|}
\hline $\begin{array}{l}\text { Jenis } \\
\text { baut }\end{array}$ & $\begin{array}{c}\text { Diameter } \\
\text { baut }\end{array}$ & $\begin{array}{c}\text { Jumlah } \\
\text { benda uji }\end{array}$ & $\begin{array}{c}\text { Kode benda } \\
\text { uji }\end{array}$ \\
\hline \multirow{4}{*}{$\begin{array}{l}\text { Baut } \\
\text { tahan } \\
\text { karat }\end{array}$} & $6 \mathrm{~mm}$ & 4 & $\begin{array}{l}\text { K6a, K6b, } \\
\text { K6c, K6d }\end{array}$ \\
\hline & $8 \mathrm{~mm}$ & 4 & $\begin{array}{l}\text { K8a, K8b, } \\
\text { K8c, K8d }\end{array}$ \\
\hline & $10 \mathrm{~mm}$ & 4 & $\begin{array}{l}\text { K10a, K10b, } \\
\text { K10c, K10d }\end{array}$ \\
\hline & $12 \mathrm{~mm}$ & 4 & $\begin{array}{l}\text { K12a, K12b, } \\
\text { K12c, K12d }\end{array}$ \\
\hline \multirow{4}{*}{$\begin{array}{l}\text { Baut } \\
\text { standar }\end{array}$} & $6 \mathrm{~mm}$ & 4 & $\begin{array}{l}\text { H6a, H6b, } \\
\text { H6c, H6d }\end{array}$ \\
\hline & $8 \mathrm{~mm}$ & 4 & $\begin{array}{l}\text { H8a, H8b, } \\
\text { H8c, H8d }\end{array}$ \\
\hline & $10 \mathrm{~mm}$ & 4 & $\begin{array}{l}\text { H10a, H10b, } \\
\text { H10c, H10d }\end{array}$ \\
\hline & $12 \mathrm{~mm}$ & 4 & $\begin{array}{l}\mathrm{H} 12 \mathrm{a}, \mathrm{H} 12 \mathrm{~b}, \\
\mathrm{H} 12 \mathrm{c}, \mathrm{H} 12 \mathrm{~d}\end{array}$ \\
\hline
\end{tabular}

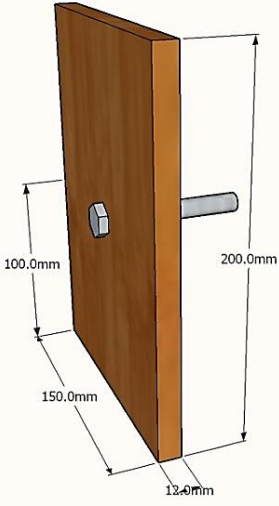

(a)

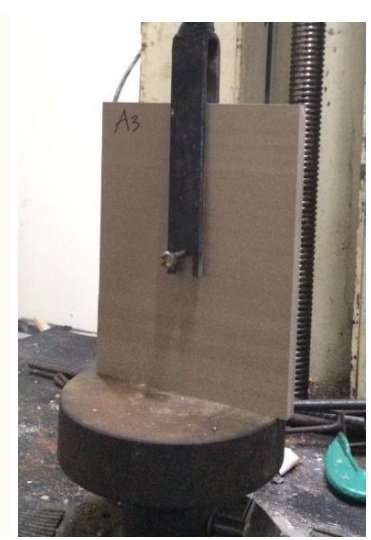

(b)
Gambar 4. (a) Dimensi benda uji pengujian; (b) Mekanisme pengujian full hole testing

\section{Hasil Pengujian}

Berdasarkan hasil analisis statistik ANOVA terhadap kuat tumpu diperoleh kesimpulan bahwa 
tidak terdapat perbedaan signifikan antara kuat tumpu (dowel bearing) baut tahan karat maupun baut standar. Pemilihan jenis baut dapat didasarkan pada peruntukannya di lapangan, untuk baut tahan karat dapat digunakan untuk peruntukan luar ruangan (outdoor) sedangkan baut standar dapat digunakan untuk peruntukan dalam ruangan (indoor).

Terdapat perbedaan signifikan untuk diameter baut yang ditinjau, baik pada baut tahan karat maupun baut standar berdasar analisis statistik ANOVA. Hasil pengujian kuat tumpu (dowel bearing) dengan baut tahan karat dapat dilihat pada Gambar 5. (a) dan hasil pengujian kuat tumpu dengan baut standar dapat dilihat pada Gambar 5. (b).

Terjadi kenaikan kuat tumpu untuk diameter $6 \mathrm{~mm}, 8 \mathrm{~mm}$ dan $10 \mathrm{~mm}$, kemudian berangsur turun di diameter $12 \mathrm{~mm}$. Penurunan di diameter $12 \mathrm{~mm}$ lebih dikarenakan semakin besar diameter baut maka semakin tinggi angka kekakuannya, hal ini menyebabkan kegagalan dominan terjadi pada papan WPC bukan pada bautnya. Semakin besar diameter juga menyebabkan deformasi penurunan lubang baut pada papan WPC menjadi semakin besar, hal ini dapat dilihat pada Gambar 4. (a) dan Gambar 4. (b) dimana beban maksimal yang terjadi berangsur semakin ke kanan.

Hal ini menunjukkan papan WPC yang mengalami kegagalan. Hasil pengujian kuat tumpu (dowel bearing) untuk baut tahan karat dapat diliat pada Tabel 2, sedangkan untuk baut standar dapat dilihat pada Tabel 3. Kuat tumpu tertinggi diperoleh pada pengujian menggunakan baut diameter $10 \mathrm{~mm}$.

Dapat dilihat pada Tabel 2 dan Tabel 3, terdapat perbedaan antara kuat tumpu menggunakan metode ultimit (beban maksimal) dan metode leleh (5\% offset) yaitu sekitar 4,62 hingga 14,14\%. Berdasarkan kedua tabel tersebut, dapat dilihat bahwa setelah diameter $10 \mathrm{~mm}$, terjadi penurunan yang diakibatkan karena kegagalan papan WPC. Mekanisme elastis yang menyebabkan deformasi pada baut $10 \mathrm{~mm}$ mampu diimbangi dengan baik oleh mekanisme elastis pada WPC sehingga menghasilkan kuat tumpu tertinggi.

Perlu dikembangkan pula studi perihal penggunaan pengencang Hal ini yang sering terjadi di lapangan, dimana akibat dari beban dinamis maka yang rusak adalah daerah di sekitar alat sambung yang dapat menyebabkan bahan material yang seharusnya tersambung menjadi lepas dari alat sambungnya.

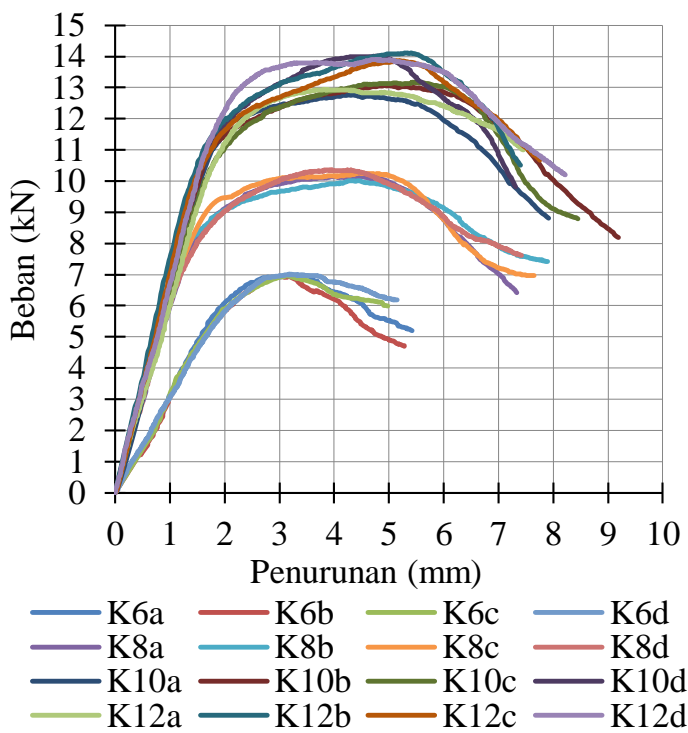

(a)

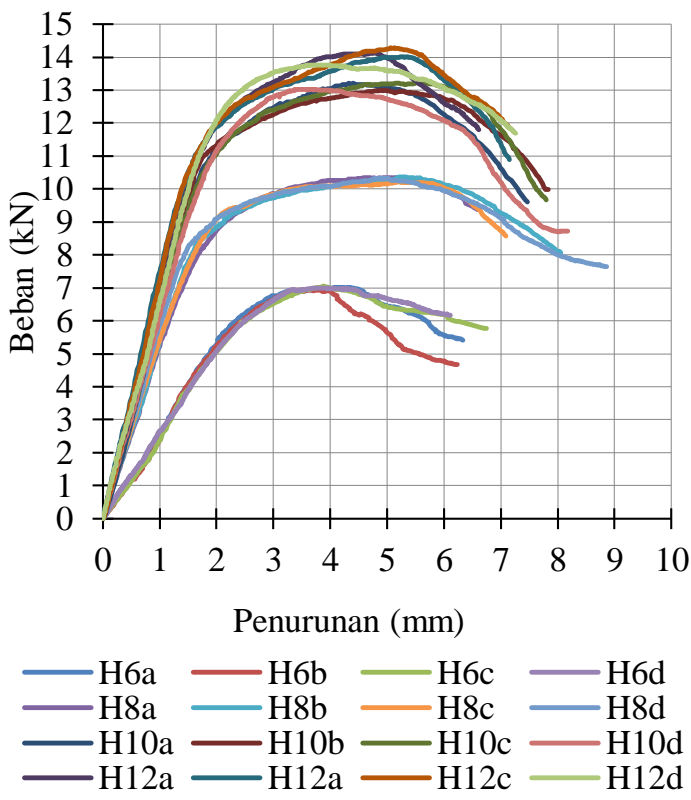

(b)

Gambar 5. (a) Hubungan beban dan penurunan pada baut tahan karat; (b) Hubungan beban dan penurunan pada baut standar

Hubungan antar diameter pada baut tahan karat dapat dilihat pada Gambar 6.a sedangkan hubungan antar diameter pada baut standar dapat dilihat pada Gambar 6.b. Berdasarkan pendekatan analisis statistik ANOVA diperoleh hasil bahwa tidak terdapat perbedaan signifikan antara baut tahan karat dengan baut standar. Keduanya memberikan kuat tumpu yang hampir sama pada masing-masing diameter, namun untuk peruntukan luar lapangan (outdoor) disarankakan menggunakan baut tahan karat untuk mengurangi potensi terjadinya karat yang dapat menurunkan kekuatan alat sambung. 


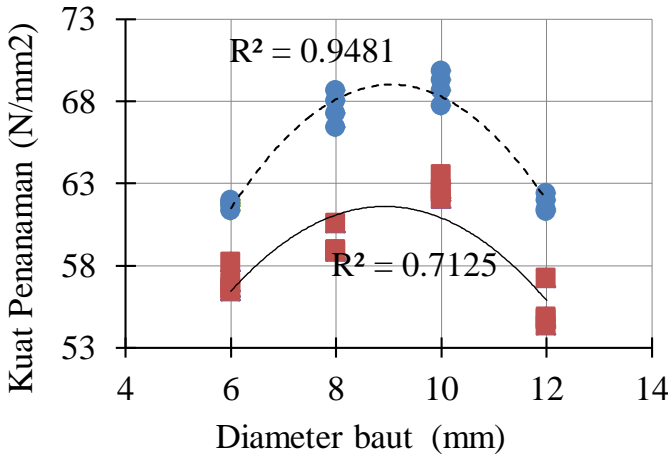

$\checkmark$ Ultimate $\triangle 5 \%$ Offset $\odot$ Ultimate $\square 5 \%$ Offset

(a)

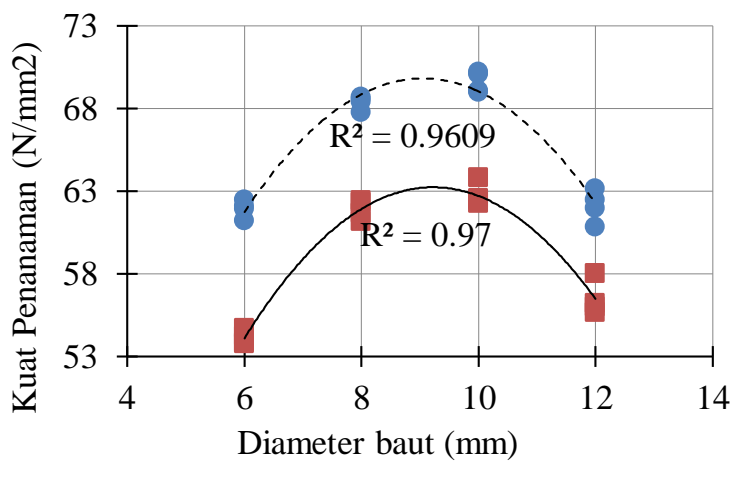

(b)

Gambar 6. a Hasil pengujian kuat tumpu baut tahan karat; 5.b Hasil pengujian kuat tumpu baut standar

Tabel 2. Hasil pengujian dowel bearing alat sambung baut tahan karat pada WPC sengon

\begin{tabular}{|c|c|c|c|c|c|}
\hline \multirow{2}{*}{$\begin{array}{c}\text { Diameter } \\
\text { baut }\end{array}$} & \multicolumn{2}{|c|}{ Metode ultimit } & \multicolumn{2}{|c|}{ Metode 5\% offset } & \multirow{2}{*}{$\begin{array}{c}\text { Persentase } \\
\text { perbedaan } \\
(\%)\end{array}$} \\
\hline & $\begin{array}{c}\mathbf{F}_{\mathrm{h}, \mathrm{u}} \\
\left(\mathbf{N} / \mathbf{m m}^{2}\right)\end{array}$ & $\begin{array}{l}\text { Penurunan } \\
(\mathbf{m m})\end{array}$ & $\begin{array}{c}\mathbf{F}_{\mathrm{h}, \mathrm{y}} \\
\left(\mathrm{N} / \mathbf{m m}^{2}\right)\end{array}$ & $\begin{array}{c}\text { Penurunan } \\
(\mathbf{m m})\end{array}$ & \\
\hline \multirow{4}{*}{$6 \mathrm{~mm}$} & 61,79 & 3,26 & 58,18 & 2,35 & 5,85 \\
\hline & 61,32 & 3,16 & 56,61 & 2,37 & 7,68 \\
\hline & 61,64 & 3,14 & 56,39 & 2,37 & 8,50 \\
\hline & 61,98 & 3,20 & 56,96 & 2,39 & 8,10 \\
\hline \multirow{4}{*}{$8 \mathrm{~mm}$} & 67,23 & 4,32 & 58,83 & 1,82 & 12,49 \\
\hline & 66,39 & 4,32 & 58,96 & 1,84 & 11,20 \\
\hline & 68,00 & 4,46 & 60,57 & 1,72 & 10,92 \\
\hline & 68,63 & 4,30 & 58,93 & 1,90 & 14,14 \\
\hline \multirow{4}{*}{$10 \mathrm{~mm}$} & 67,70 & 4,27 & 63,53 & 2,23 & 6,15 \\
\hline & 69,29 & 4,92 & 62,45 & 2,27 & 9,87 \\
\hline & 69,83 & 5,46 & 62,03 & 2,37 & 11,17 \\
\hline & 68,63 & 3,80 & 62,64 & 2,26 & 8,73 \\
\hline \multirow{4}{*}{$12 \mathrm{~mm}$} & 61,98 & 4,86 & 54,72 & 2,32 & 11,72 \\
\hline & 62,37 & 5,30 & 54,87 & 2,31 & 12,02 \\
\hline & 61,28 & 5,20 & 54,33 & 2,46 & 11,34 \\
\hline & 61,39 & 4,85 & 57,21 & 2,26 & 6,81 \\
\hline
\end{tabular}

Tabel 3. Hasil pengujian dowel bearing alat sambung baut standar pada WPC sengon

\begin{tabular}{|c|c|c|c|c|c|}
\hline \multirow{2}{*}{$\begin{array}{l}\text { Diameter } \\
\text { baut }\end{array}$} & \multicolumn{2}{|c|}{ Metode ultimit } & \multicolumn{2}{|c|}{ Metode 5\% offset } & \multirow{2}{*}{$\begin{array}{c}\text { Persentase } \\
\text { perbedaan } \\
(\%)\end{array}$} \\
\hline & $\begin{array}{c}\mathbf{F}_{\mathrm{h}, \mathrm{u}} \\
\left(\mathbf{N} / \mathbf{m m}^{2}\right)\end{array}$ & $\begin{array}{l}\text { Penurunan } \\
(\mathbf{m m})\end{array}$ & $\begin{array}{c}\mathbf{F}_{\mathrm{h}, \mathrm{y}} \\
\left(\mathrm{N} / \mathbf{m m}^{2}\right)\end{array}$ & $\begin{array}{l}\text { Penurunan } \\
(\mathbf{m m})\end{array}$ & \\
\hline \multirow{4}{*}{$6 \mathrm{~mm}$} & 62,09 & 4,10 & 54,70 & 2,48 & 11,90 \\
\hline & 61,22 & 3,81 & 54,22 & 2,55 & 11,43 \\
\hline & 62,45 & 3,89 & 53,84 & 2,59 & 13,79 \\
\hline & 61,91 & 3,83 & 53,77 & 2,55 & 13,16 \\
\hline \multirow{4}{*}{$8 \mathrm{~mm}$} & 68,55 & 5,12 & 61,16 & 2,31 & 10,79 \\
\hline & 68,66 & 5,25 & 61,68 & 2,36 & 10,17 \\
\hline & 67,74 & 5,26 & 62,41 & 2,27 & 7,87 \\
\hline & 68,40 & 5,02 & 62,30 & 2,32 & 8,92 \\
\hline \multirow{4}{*}{$10 \mathrm{~mm}$} & 70,08 & 4,41 & 62,24 & 2,40 & 11,19 \\
\hline & 68,96 & 4,96 & 62,47 & 2,41 & 9,41 \\
\hline & 70,19 & 5,56 & 62,53 & 2,40 & 10,91 \\
\hline & 69,07 & 3,74 & 63,83 & 2,42 & 7,60 \\
\hline \multirow{4}{*}{$12 \mathrm{~mm}$} & 62,45 & 4,77 & 55,99 & 2,45 & 10,34 \\
\hline & 61,96 & 5,26 & 55,68 & 2,51 & 10,14 \\
\hline & 63,13 & 5,07 & 56,19 & 2,49 & 11,00 \\
\hline & 60,84 & 3,77 & 58,03 & 2,54 & 4,62 \\
\hline
\end{tabular}


Pendekatan ANOVA juga dilakukan untuk mengetahui ada tidaknya perbedaan signifikan perbedaan diameter yang digunakan pada masingmasing jenis baut. Berdasar hasil ANOVA tersebut terdapat perbedaan signifikan pada kuat tumpu untuk diameter $6 \mathrm{~mm}, 8 \mathrm{~mm}, 10 \mathrm{~mm}$ dan $12 \mathrm{~mm}$. Dikarenakan pada penelitian ini diameter $10 \mathrm{~mm}$ menghasilkan kuat tumpu tertinggi, maka dapat direkomendasikan untuk sambungan struktural WPC digunakan baut dengan diameter $10 \mathrm{~mm}$.

Berdasarkan pengamatan setelah pengujian, baut diameter $6 \mathrm{~mm}$ dan $8 \mathrm{~mm}$ sepenuhnya bengkok akibat dari beban lateral. Pada baut diameter 10 $\mathrm{mm}$ hanya sedikit mengalami bengkok namun pada saat yang bersamaan papan WPC juga mengalami kegagalan lokal, hal tersebut yang membuat baut diameter $10 \mathrm{~mm}$ memberikan kuat tumpu tertinggi dibandingkan diameter baut lainnya. Kegagalan pada baut diameter 10 dapat dilihat pada Gambar 7.

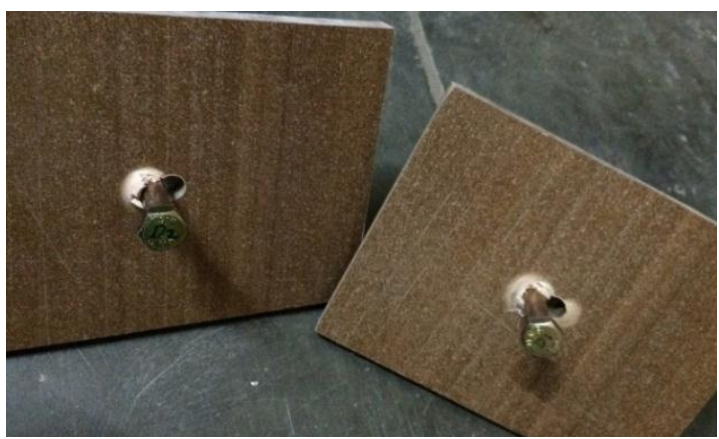

Gambar 7. Gagal lokal papan WPC sengon akibat beban lateral baut diameter $10 \mathrm{~mm}$

\section{Kesimpulan}

Berdasar analisis statistik ANOVA tidak terdapat perbedaan signifikan antara jenis baut tahan karat dan baut standar, hal ini menunjukkan kedua jenis baut tersebut memiliki kekuatan yang hampir sama namun apabila berada di luar ruangan dianjurkan menggunaan baut tahan karat untuk mengurangi terjadinya karat yang lambat laun dapat mengurangi kekuatan alat sambung. Berdasarkan ANOVA terdapat perbedaan signifikan untuk besaran diameter baut yang digunakan, sehingga dapat ditarik kesimpulan bahwa baut ukuran $10 \mathrm{~mm}$ direkomendasikan penggunaannya untuk sambungan struktural karena berdasarkan hasil pengujian dengan standar ASTM D5764 - 97a diperoleh kuat tumpu tertinggi pada diameter tersebut. Kesimpulan ini dapat digunakan sebagai dasar pemilihan diameter baut pada penelitian alat sambung yaitu penggunaan papan WPC Sengon sebagai dinding geser karena memiliki kuat geser tinggi. Diameter $6 \mathrm{~mm}$ dan $8 \mathrm{~mm}$ mengalami bengkok akibat dari pengujian sehingga kuat tumpunya rendah, pada diameter $10 \mathrm{~mm}$ baik baut maupun WPC Sengon mengalami kegagalan bersamaan. Untuk baut diameter $12 \mathrm{~mm}$ akibat dari kekakuan baut itu maka menyebabkan papan WPC mengalami kegagalan terlebih dahulu.

\section{Ucapan Terima Kasih}

Terima kasih yang tak terhingga penulis sampaikan kepada semua pihak yang telah membantu terlaksananya penelitian ini. Secara khusus kepada Promotor dan Co-Promotor atas semangat dan masukan yang telah diberikan dari awal hingga terselesaikannya penelitian ini.

\section{Daftar Pustaka}

American Wood Council, 2014. Technical Report 12 - General Dowel Equations for Calculating Lateral Connection Values, Leesburg.

Anonim, 2014. Statistik Kementerian Kehutanan Tahun 2013, Kementerian Kehutanan, Jakarta.

Arnandha, Y., 2016. Physical and Mechanical Properties of WPC Board from Sengon Sawdust and Recycled HDPE Plastic, Prociding of Sustainable Civil Engineering Structures and Construction Materials (SCESCM), Bali.

ASTM D5764 - 97a, 2013. Standard Test Method for Evaluating Dowel-Bearing Strength of Wood and Wood-Based Products, ASTM International, West Conshohocken, PA, www.astm.org.

Aune, P., Mallory, M., P., 1986. Lateral Load Bearing Capasity of Nailed Joints Based on the Yield Theory, Forest Product Laboratory, United States Department of Agriculture.

Awaludin A., 2005. Dasar-dasar Perencanaan Sambungan Kayu, Biro Penerbit Teknik Sipil, Universitas Gadjah Mada, Yogyakarta.

Awaludin A., Smittakorn W., Hirai T., 2007. Bearing Properties of Shorea Obtusa beneath a Laterally Loaded Bolt, Journal Wood Science 53(3), p. 204-210.

Gattesco N., 1998. Strength and Local Deformability of Wood Beneath Bolted Connectors, Journal of Structural Engineering, vol. 124, pp. 195-202.

Hassan R., Azmi I., Zakiah A., 2014. DowelBearing Strength Properties of Two Tropical Hardwood, Proceedings of the International Civil and Infrastructure Engineering Conference 2013 
(InCIEC 2013), ISBN No.: 978-981-4585-01-9 (Print), p. 27-36.

Humbert, J., Boudaud, C., Baroth, J., Hame, S., 2014. Joints and Wood Shear Walls Modelling I: Constitutive Law, Experimental Tests and FE Model Under Quasi-static Loading, Engineering Structures, vol. 65, pp. 52-61.

McLain T., E., Thangjitham S., 1983. Bolted Wood-Joint Yield Model, Journal of Structural Engineering, vol. 109, pp. 1820-1835.
Tabarsa T., Khanjanzadeh, H., Pirayesh, H., 2011. Manufacturing of Wood-Plastic Composite from Completely Recycled Materials, Key Engineering Materials Vols. 471-472 (2011) pp 62-66, Trans Tech Publications, Switzerland, doi:10.4028/www.scientific.net/KEM.471-472.62

Whale L.R.S., Smith I., 1986. The derivation of design values for nailed and bolted joints in EUROCODE 5, Working Commission 18, Timber Struct., Meeting 19, Int. Council for Build. Research Studies and Documentation. 